\title{
The Concept of Religion in Current Studies of Scandinavian Pre-Christian Religion
}

\author{
ANETTE LINDBERG \\ Stockholm University
}

\begin{abstract}
In recent Swedish studies of Scandinavian pre-Christian religion of the late Iron Age, various scholars have questioned the utility of the concept of religion in this field. According to these scholars, the concept of religion obscures the specific character of religions of the small-scale non-literate societies of the pre-Christian Age. In the article, I critically examine suggestions that we abandon the academic concept of religion and replace it with an emic concept, or a concept derived from an emic context. I further argue that this strategy implies an inappropriate dualistic opposition between Scandinavian pre-Christian religion and so-called world religions. I conclude with a critical evaluation of problematic formulations of religious change and variation, presented by the same scholars who criticize the use of the academic category of religion. I try to draw attention to certain problematic implications of these demands. I conclude that we should continue to employ the concept of religion in connection with the religious worlds of pre-Christian societies. The strategy proposed by these scholars may turn out to be merely one more way of imposing misconceptions on this period.
\end{abstract}

Keywords: concept of religion, archaeology of religion, pre-Christian Scandinavia, emic and etic concepts, ethnocentrism

In various recent Swedish studies on Scandinavian pre-Christian religion ${ }^{1}$ by archeologists and historians of religions, we find statements regarding the usefulness - or rather non-usefulness - of the core concept of 'religion'. Some of these scholars, in voicing their doubts as to the utility of this category, have proposed that we abandon the concept, since it is far too permeated

1 In this article I use the label 'Scandinavian pre-Christian religion' to refer to the religion of the late Iron Age in this area. This period includes approximately the last 500 years of the first millennium CE. I use this term similarly to the use of the term 'Old Norse religion' by various authors in reference to the religious conceptions and activities of the societies of this period in Scandinavia. 
with ethnocentric preconceptions. In applying the concept of religion, they say, we misconceive the religious worlds of pre-Christian societies. As they put it, we are imposing western and modern Christian ideas of religion on the Scandinavian pre-Christian period.

Such claims have most likely been inspired by contemporary discussions and reflections on the concept of religion in the disciplines of History of Religions and Social Anthropology. While consideration of the concept, and attempts to define it, have a long history in the study of religion, some scholars of Scandinavian pre-Christian religion have probably been influenced by the recent debate stimulated by deconstruction and critical reflection in post-modern and post-colonial theoretical studies.

In this article I want to introduce certain critical reflections on these objections to the concept of religion, and to discuss the proposals put forward in studies of pre-Christian Scandinavia. Some scholars have suggested that the concept of religion be replaced by an emic term. I suspect such a shift would create far more problems than its advocates seem to be aware of. I therefore want to scrutinize the development of statements and arguments by these scholars in the fields of History of Religions and Archaeology, in their critique of the concept and analytical category of religion.

A question I wish to ask is whether this abandonment of the concept of religion has led to a better understanding of pre-Christian religious beliefs and practices. My initial answer to this question is this: I am not convinced that the improvements are as significant as has been implied by the critics.

In order to avoid misunderstanding, it is important to emphasize one point: I am not implying that a critical consideration of the applicability of our analytical concepts, such as 'religion', and of possible implicit biases in our studies in general, is unimportant. Quite the contrary: the debate and the critique of the concept of religion have among other things highlighted the problems of subjectivity and biased preconceptions in scholarly work. They have made us aware of how our theories, and our implicit prejudices and preconceptions, can influence and restrict what we as scholars define as religion. And questions have been raised as to the issues of power involved in who gets to decide what counts as religion.

It is not my primary aim in this article to provide an overall review of the debate in the History of Religions and in Social Anthropology on the concept of religion - it is far too extensive to be recapitulated here although I will make some occasional comments on the prolific work that has been accomplished in this area. Despite my assumption of a connection 
between the theoretical discussion in the disciplines of History of Religions and Social Anthropology and the arguments put forward in archaeological studies on this topic, I would like to emphasize that I suspect this connection, in most cases, is only second-hand and quite superficial. My main focus here, however, is on a critical review of the way in which certain scholars in Archaeology and History of Religions have conceptualized Scandinavian pre-Christian religion.

In what follows I start by summarizing the discussion of the concept of religion in the disciplines of History of Religions and Social Anthropology, seeking to pinpoint the main arguments presented in studies inspired by post-modern and post-colonial theories. I also briefly comment on the extensive debate over the definition of religion.

After introducing these theoretical issues, with their conceptual problems and difficulties, I outline the main arguments concerning the concept of religion in archaeological and religio-historical pre-Christian studies. I start by examining the thinking of one particular scholar, who seems to be the main inspiration for the current critique of the concept of religion in archaeology. This is Torsten Blomkvist, a historian of religion working mainly in an archaeological tradition. Blomkvist has, among other things, advocated the application of an indigenous concept of religion as a substitute for the analytical one, as a more adequate designator for the religious beliefs and practices of pre-Christian societies in Scandinavia. Since Blomkvist's proposal is in some respect problematic, I examine his arguments and try to outline the consequences his approach may have for the study of pre-Christian religion in Scandinavia. I further explore the difficulties such a strategy may imply in a broader comparative perspective, i.e. in cross-cultural studies of religions.

I then introduce some critical comments on those archaeologists who put forward arguments similar to those of Blomkvist. Since I am not in agreement with this approach, I argue for the continued usage of the concept of religion in the field of the study of pre-Christian ritual practices and of religious conceptions such as symbolic systems and myths.

In the concluding sections my intention is to evaluate the statements of religious change and variation maintained by archaeological authors, on defining the religion of pre-Christian Scandinavia, which a historian of religion may find problematic. 


\section{The Current State of Discussion Concerning the Concept of 'Religion' in the Study of Religion}

The academic discussion of what religion is and how it should be defined is an ongoing process with a long history in the scholarship of religion (for an overview, see Saler 1993). An issue that has been prevalent in contemporary studies is whether or not the dominant focus, in earlier studies, on systems of beliefs has produced biased accounts of many religions, leading us to miss the diversity of religious expression in the world (e.g. Asad 1993; cf. Godlove 2002 \& Modée 2005, 10-41). In short, the critics have argued that it is beliefs and cognitive aspects of religion that have stood at the centre of the scholarly studies and been seen as the most important object of study or the main feature of religions. This primacy of religious beliefs led scholars to ignore other important characteristics of religious expressions. A one-sided focus on belief and belief systems served to detach belief from practice, raising an artificial boundary between religious beliefs and religious activities, and further veiling the interrelatedness of on the one hand cultural conceptions and religious beliefs, on the other social conditions and religious practices (e.g. Asad 1983). This biased perspective, based on a modern understanding of religion derived from Christian Protestantism, thus conceals the total picture and complexity of the different characters of the many religions which we find both in the present-day world and in historical times (cf. Bilde 1991, 13).

This critique led to a change of perspective in the study of religion, in which the previously ignored aspect of religious action came to be highlighted. While studies for example of rituals are of course not a new phenomenon in the study of religion, I would say that the theoretical debate over the concept of religion, and of ritual, has led among other things to a greater emphasis on religious action as a dynamic process, through which people continually and actively create and negotiate cultural conceptions and their social worlds. New areas of interest in the study of religions include for example those focusing on practice, performance and embodiment (see Bell 1997).

An attempt to summarize the extensive debate on the category of religion reveals two main trends (McCutcheon 1997, 127-57; Modée 2005, 10-41). One of these has its focus on definitions of religion. Attempts to define religion are as old as the discipline itself; hence there has been constant debate among various scholars, yielding an abundance of different and contesting definitions within the scholarship of religion (Bilde 1991; Geertz 1996; Jonathan Z. Smith 1998). These debates have in fact led some 
scholars to conclude that religion is almost impossible to define (cf. Saler 1993).

The other trend has centred primarily on deconstructing the concept of religion; these scholars call the concept itself into question, asking whether it can really be applied at all as a universal or cross-cultural category (e.g. Asad 1993; Fitzgerald 1997; cf. Saler 1993; for an overview of the discussion, see McCutcheon 1997). Those who advocate this standpoint further speak of the problems of demarcating the concept in such a way as to allow its application as a general category. According to some scholars, no universal or ahistorical definition of religion is in fact possible, since religious expressions are always context-bound. Or, as the anthropologist Talal Asad puts it:

[T]here cannot be a universal definition of religion, not only because its constituent elements and relationships are historically specific, but because the definition is itself the historical product of discursive processes (Asad 1993, 29).

This questioning of the concept of religion has mainly been influenced by post-modern and post-colonial theories. According to the advocates of these theoretical orientations, the concept of religion is an academic construction situated in a particular historical period, and is part of a western cultural conception. They therefore criticize it as being contaminated by ethnocentric and Eurocentric biases. For example, the conceptualization of religion as a private matter and with a focus on belief is part of a western notion; even though this is a 'folk' definition, used in common speech, these critics suggest that such cultural notions permeate professional conceptualizations and categories as well (cf. Saler 1993, 8ff). Thus the study of religion is seen as a project of imperialism, which has led to the oppression of the 'Other'. In his article 'A Critique of "Religion" as a Cross-Cultural Category' Timothy Fitzgerald writes:

Even attempts by scholars with a non-theological agenda to refine the concept of religion and make it work as non-theological analytical tool fail, for meanings are not merely a question of definition but also of power. I suggest that this category is now far too deeply embedded in a legitimation process within western societies, in the dominant relation of those societies with non-western societies, or with various ethnic minorities living within western societies, to be successfully liberated from the semantic hold of liberal ecumenical theology. Consequently the way forward for those scholars 
working within religion departments who do not have a theological agenda, but who recognize the phenomena usually described as religion as being fundamentally located within the arena of culture and its symbolic systems, is to redescribe and represent their subject matter as the study of institutionalized values in different societies and the relation of those values to power and its legitimation. Personally, I would be happy to call this Humanities or Cultural Studies. (Italics in original, Fitzgerald 1997, 95.)

The historian of religion Jonathan Z. Smith critically writes that the concept of religion, and its study, is an academic construction emanating from a modern European context. In the very title of his book, Imagining Religion (1982), Smith conveys the basic idea of his critique in an intriguing but provocative manner, telling us that religion is something created in the minds of scholars. In the introduction to this book Smith tells us:

[W]hile there is a staggering amount of data, of phenomena, of human experiences and expressions that might be characterized in one culture or another, by one criterion or another, as religious - there is no data for religion. Religion is solely the creation of the scholar's study. It is created for the scholar's analytic purposes by his imaginative acts of comparison and generalization. Religion has no independent existence apart from the academy. (Italics in original, Jonathan Z. Smith 1982, xi.)

Smith tells us to critically examine the way much scholarly work is a product of our analytical purposes, eloquently urging us to be self-conscious and selfreflective. But if one holds the view that religion is a scholarly construction, then one consequence of such a statement would be that such conceptual categories as for example economy, politics, law and art ought to face the same problem. Other examples of abstractions are power, a concept often applied by Asad, and ideology. If, as argued by Asad, we cannot apply a universal definition of 'religion', can we use these other categories? As scholars we should always be aware of the epistemological foundations and historical contingencies of our concepts, but this need not prevent us from applying them. Analytical categories and abstractions, such as 'religion' and the other concepts mentioned above, are necessary heuristic tools in our empirical research.

Furthermore, I am not convinced that the study of different societies and cultural systems is merely a way of inventing knowledge, with no basis in an empirical context (cf. Jensen 2003, 111; Modée 2005, 36-8). While 
academic research is naturally the result of a constructed academic process, composed out of our conceptualizations, specific questions, and constructed categories, I do think that the category of religion represents an entity that correlates with something 'out there' in social reality, at least as much as any other abstract category such as culture, economy, politics or gender (cf. Beyer 2003, 151). ${ }^{2}$

In his study of the conceptual analysis of the definition of religion, the philosopher of religion Johan Modée argues against the relativistically influenced post-colonial objection that a universal category of religion is impossible to sustain.

Consequently we can reject the claim that 'religion' cannot have a universal application just because concepts are constructed from different point of views. It is simply not the case that cultural differences and historical contingencies exclude the possibility of a universally valid definition. And it is not the case that mere differences in epistemic perspectives and conceptualizations exclude the possibility that we might have an epistemic access to what can be categorized universal ontological characteristics of every social feature. (Italics in original, Modée 2005, 38.)

Modée's point of view is interesting, although I do not think creating such a definition is an uncomplicated task. Previous definitions have various shortcomings: for example, they are often presented in a mere one or two sentences, which because of their narrowness and generality are bound to miss the total complexity and diversity of the phenomenon (Bilde 1991, 4; Saler 1993, 156). These narrow definitions tend to highlight just one or a few central characteristics of religions. One example is E. B. Tylor's well-known definition of religion as a 'belief in spiritual beings' $(1970,9)$. Other definitions tend to be overly vague, and fail to embrace the specific conceptions and practices that distinguish religions from other cultural and social phenomenon; this vagueness is perhaps exemplified in Clifford Geertz's definition of religion, even though his definition in a positive manner situates religion in a cultural and social context. According to Geertz:

[A] religion is: (1) a system of symbols which acts to (2) establish powerful, pervasive, and long-lasting moods and motivations in men by (3) formulating

2 See also the discussion on this issue by McCutcheon $(1997,26,130)$ and Jensen (2003, 413). 
conceptions of a general order of existence and (4) clothing these conceptions with such an aura of factuality that (5) the moods and motivations seem uniquely realistic (Geertz 1973, 90).

The shortcomings of many of the definitions proposed over the years make it understandable that many critics have concluded that religion is almost impossible to define. Even so, I am not sure I agree with this conclusion. Since, however, religion is a complex phenomenon, one which can be studied from many different angles and perspectives, I also do not think it is possible to formulate a single brief definition or sharp demarcation with which all of us could agree, nor am I sure this is what is needed. Perhaps the strategy proposed by Benson Saler is one that would work. Saler proposes a multifactorial approach (1993), in which no single feature is deemed essential, for developing explicit open-ended definitions of the category of religion. According to Saler, this 'renders religion an affair of more or less rather than, as in the digitized constructs employed by essentialists, a categorical matter of "yes" or "no"' $(1993,25)$. The focus of this approach on 'moreor-less' definitions can help us abandon a category of religion defined in definitive either-or terms.

The members of an unbounded category are determined according to a loose set of family resemblances. Initially this evolves out of a prototypical notion of what scholars decide constitutes a religion; the conceptualization and explication of the category then takes place by means of comparing similarities and analogies with reference to this 'norm'. For analytical purposes, the category of religion is thus according to Saler best conceptualized 'in terms of a pool of elements that more or less tend to occur together in the best exemplars of the category' $(1993,225)$. The use of prototypes and unbounded categories, however, should always be used tentatively; furthermore, Saler tells us, they need to be constantly open to revision. This method, according to Saler, can help scholars detect implicit biases in their conceptualizations and background assumptions.

A category of religion without conceptual boundaries is a creative approach which leaves us more open-minded to a less rigid demarcation between religions and other social phenomena which share similar features of religious expression. According to a review by Brian Morris, this strategy 'acknowledges the complexity and variability of religious phenomena, the ambiguity and vagueness inherent in all attempts to define social categories, and the fact that there can be no hard-and-fast line in the demarcation of religion' (Morris 1994, 178). 
For most scholars, however, defining 'religion' is not a major problem in their daily routine. As Peter Beyer writes in a straightforward manner in his article on the difficulties of such definitions:

[T]he discipline in fact, for the most part, proceeds in practical terms as if religion were a reasonably clear category [...] Scholars of religion do not thereby forget about the ambiguities: rather, the notions of religion and the religions are matters of practical consensus, not of agreed upon definition. (Beyer 1998, 2-3.)

To conclude: I would like to note that problematic definitions of religion are found in many cases, and that problematic bias is sometimes unavoidable. Nevertheless I do not think this is a problem that is necessarily embedded in the concept of religion itself, since evidently many scholars do use it without these Christian and Eurocentric preconceptions. I do not think abandoning the concept of religion is a productive solution. The proposal to instead call the study of religion 'Cultural Studies', as recommended by Fitzgerald (1997, $93,95)$, is a troublesome strategy; even if we place religion within the realm of culture, Fitzgerald's solution would make us miss the distinctive character expressed in religious activities and beliefs (cf. Jensen 2003, 17).

Asad's statement that there can be no universal definitions because different definitions are products of different historical contexts is interesting in that it emphasizes the situatedness of our concepts. However, there is no reason to believe that this prevents us from using the academic concept of religion in a generic manner. Modée criticizes Asad's conclusion, declaring that 'Asad has not demonstrated that a "universal definition" of religion is impossible. At best, he has indicated that there are historical differences in how to conceptualize religion.' (Modée 2005, 39.) These historical differences in the conceptualization of religion, and the distinctive character of different religions in different times and places, are not in my view sufficient cause to abandon the academic category of religion. These differences point a spotlight at the diversity of religious expressions, but this should not prevent us from using the category of 'religion' as an academically defined concept. The historian of religion Russell T. McCutcheon has commented critically on Asad's recommendation (1983, 251;1993, 54), according to which scholars of particular religions should avoid a universally defined concept of religion and instead investigate particular indigenous conceptualization of religious practices and conceptions in their specific historical and social contexts. McCutcheon writes: 
Although this respect for local details is most important, one cannot help but think that Asad's recommendation lands the researcher in a bit of a problem. As important as it is to avoid universal generalization that effectively ignore local details, it is equally problematic to generalize about ' particular religions'. [...] Asad's recommendation all but rules out generating widely applicable, cross-cultural theories [...] Hence, Asad's well-intentioned advice turns out to be not so easy to follow. (McCutcheon 1997, 133-4.)

In the next section I focus on the conceptualization of religion among certain scholars of pre-Christian religion in Scandinavia, who argue that we need to abandon the concept of religion. The views of these authors have been more or less influenced by the debate on this issue among historians of religion and anthropologists, as discussed above.

\section{Recent Questioning of the very Concept of Religion in Studies of Scan- dinavian Pre-Christian Religion}

The study of religion in Archaeology has grown, from an almost non-existent field of study during the 1960s and 70s, to become an exceedingly popular subject (Jennbert 2000). This is in many ways an interesting turn. We may assume that religion was as important a factor in human lives in prehistoric societies as it is today. But the reconstruction of religious activities from prehistoric material is a complex and intricate endeavour. These complexities are, understandably, a much-debated issue in the field of archaeology. In the case of the pre-Christian religion of the late Iron Age in Scandinavia we have a wealth of written sources in Old Norse texts especially from the thirteenth century, going back in part to earlier texts and the oral tradition, which makes this field a fascinating and exciting period of study. The use of historical sources, however, requires philological training in the Old Norse languages. Thus the study of pre-Christian religion is a complex field, requiring a multi-disciplinary approach.

Recent studies of Scandinavian pre-Christian religion have questioned the utility of the concept of religion in this field, suggesting that the concept be abandoned and replaced with an emic term. This attempt to deconstruct or question the concept of religion is based in part on the ideas of post-modern and post-colonial theories, but often in a second-hand and somewhat superficial manner. What is even more noteworthy is that many of the archaeologists who question basic concepts and theories in the study of religion do so without any deeper knowledge of the history of research 
concerning these concepts and theories. In the following, I present the arguments made by these scholars and analyse the problematic consequences their claims may entail.

In an archaeological study focusing on social changes during the Iron Age and the Middle Ages in Gotland, Sweden, the historian of religion Torsten Blomkvist (2002) suggests among other things that the study of pre-Christian religion in Scandinavia is in need of a new and different classification. Instead of the supposedly biased concept of religion, Blomkvist urges us to use the term 'ritualized tradition' in dealing with the religious expressions of Iron Age societies. This concept of 'ritualized traditions' is Blomkvist's (2002, 23-27) translation of the indigenous term siðr, which we find in the written sources of Old Norse texts and Medieval provincial laws. The term siðr can be translated by the English term 'custom' (Sundqvist 2005).

Blomkvist reserves the 'old' concept of religion - or rather the term he prefers to use, 'institutionalized religion' - for Medieval Christianity in the North. The reason for this, as he himself puts it, is that 'the use of "religion" is often based on ideas that are anchored in a Christian Western discourse' (Blomkvist 2002, 195). ${ }^{3}$

Blomkvist's brief discussion of his questioning of 'religion' (2002, 9-14) is supported by references to Wilfred Cantwell Smith, Gregor Ahn and Timothy Fitzgerald. In his discussion of the notion of turning an indigenous concept into an analytical category, Blomkvist is inspired by a proposal by Benson Saler (see below).

It is, however, obvious that Blomkvist's thinking and writing about 'religion' is permeated by his own preconceptions. His definition of 'religion' seems to be modelled on modern Protestantism, with its emphasis on innate personal religiosity and its focus on religious faith. His critique of the applicability of the concept of 'religion' to the small-scale societies of pre-Christian Scandinavia, and his view that 'religion' is embedded in Christian and Eurocentric biases, are supported by an entry in a theological encyclopaedia (Ahn 1997).

Further on, Blomkvist's definition of religion relies on Smith's critique of the concept. Smith's suggestion, made in the sixties, of abandoning 'religion' and replacing it with the concepts of 'cumulative tradition' and 'personal faith' (Wilfred Cantwell Smith 1978, 156), evolved out of what might be called a theological insider perspective which seems all too biased. His

3 The quotations from Blomkvist in this article are from the English summary in Från ritualiserad tradition till institutionaliserad religion ['From ritualized tradition to institutionalized religion']. 
focus on 'interior and generally inaccessible personal experiences and religious convictions' takes place, in the words of McCutcheon $(1997,128)$, 'at the expense of observable, documentable data'. Since Smith's own work is highly coloured by a modern liberal Christian perspective, he is obviously not the most suitable authority when it comes to evaluating religion as a category in cross-cultural studies (cf. Kværne 1973). The main inspiration for Blomkvist's way of thinking, however, seems to be Fitzgerald's radical critique of 'religion' as a cross-cultural analytical category (see above), and the troublesome and tendentious arguments concerning the Eurocentric and Christian understanding of religion in the contribution by Ahn. ${ }^{4}$

The reason for Blomkvist's introduction of the concept of 'ritualized tradition' is his conviction that the concept of religion, as he understands it, obscures the specific character of the religions of the small-scale non-

4 In questioning the very term 'religion', Ahn seems to be caught in an outdated evolutionist understanding of the term. According to him, it emanates from an apprehension of religion as belief/worship in one or several gods/goddesses, which, he says, is an extended version of the originally theological definition of religion as belief in God. This theistic definition includes monotheistic and polytheistic religions. When Europeans in the eighteenth and nineteenth century began to study non-European societies, they had to adjust their perceptions of religion. According to Ahn, the belief in and worship of spirits of different kinds, ancestors as well as supernatural powers, found in simpler societies, were incompatible with the Eurocentric theistic understanding of religion. In Ahn's view, scholars were therefore forced to develop an enlarged definition of religion in which these 'pre-theistic' religions could be included as early evolutionary stages of the 'true religions', i.e. as 'animism', 'manism' and 'dynamism' ('preanimism'). Ahn seems to be unaware of the fact that the 'pre-theistic' stages postulated by Tylor, Spencer, Marett etc. have long since been abandoned in religio-anthropological research as outdated. Such 'pre-theistic' religions hardly exist. On the other hand, conceptions such as 'animism', 'manism' and 'dynamism' are phenomenologically part of most religions, both those of small-scale societies and the so-called 'world religions' - Judaism, Christianity, Islam, Hinduism and Buddhism. And theism is certainly a vital part of the religions of the world.

When it comes to Buddhism, Ahn polemicizes strongly and astonishingly against Geo Widengren, who in Religionens värld (the German Religionsphänomenologie) makes the assumption that the cosmic principle dharma may have developed out of the aspect of fate bound to an earlier divinity of fate. This of course cannot be proved, but it seems to be closer to common sense to try to explain the very specific as a development out of the more general than the opposite. Ahn claims that classic Buddhism, along with 'animism', 'manism' and 'dynamism' do not fit the theistic definition of religion.

Ahn not only opposes a definition of religion that implies a ritual and metaphysical relationship between humans and god/gods, he also opposes the broader idea that religion implies a relationship between humans and a transcendent reality (personal or non-personal). A transcendent reality, he maintains, is beyond what science can confirm, and should be replaced by scientifically verifiable criteria. This, according to Ahn, is also applicable to such concepts as 'supernatural' and 'holy'. If this were so, the History of Religion would certainly become an impossible discipline! Obviously he confuses conceptions held by individual human beings and cultures with reality itself. 
literate societies of the pre-Christian Age. He tells us that 'pre-Christian religion seems to have been socially and culturally integrated in another way than later Christianity' and that '[i]nherent in the discourse of religion, there is also a problem that arises when trying to adjust or redefine it to the "non-literate" societies' (2002, 195-6). He declares that a different concept would give us a new understanding of the religious practices of pre-Christian Scandinavia. This would allow us to perceive religious activities and conceptions as an integral part of the society (Blomkvist 2002, 15ff). Similar statements have been made by archaeologists criticizing the concept of religion for obscuring our understanding of pre-Christian religious practices as incorporated into the cultural and social spheres (e.g. Jennbert 2000, 129; Artelius \& Svanberg 2005, 8). This kind of brash statement seems to arise out of ignorance of the current anthropological study of the religion in smallscale, non-literate societies, where social integration is a well established fact not calling into question the very notion of religion itself (see Harvey 2000, 2; Cox 2007, 3).

Blomkvist further writes that the concept of religion implies a static and homogeneous perspective on the pre-Christian religion of Scandinavia (Blomkvist 2002, 8, 13). It is important to note, however, that while some previous studies may have problematically depicted pre-Christian religion in Scandinavia in such a way, this is not something inherent in the concept of religion. The fact that religions - and this holds for small-scale non-literate societies as well - are far from static is not a new insight, but on the contrary is self-evident in the current anthropological study of religion. As suggested by these studies (with which Blomkvist does not seem to be familiar), we definitely do not need a new category for the study of the religion of preChristian Scandinavia in order to acknowledge that religions are not static and homogeneous.

Instead of abandoning the concept of religion, the more sensible thing to do is to discuss what it is all about and how we should perceive it, hopefully enabling us to identify the best methods for studying the religions of pre-Christian societies (cf. Joy 2008, 201-2). In any case, merely replacing an analytical concept will not necessarily rid us of ethnocentrism. The proposed strategy may turn out to be simply another way of imposing misconceptions on this period.

According to Blomkvist, his new analytical concept of 'ritualized tradition' better describes action-oriented forms of religious expression, which according to him is a more accurate perspective on the religion of the preChristian period (Blomkvist 2002, 23ff.). So-called 'ritualized traditions' 
or religious activities are additionally embedded in a process of political change, which, if I have understood Blomkvist correctly marks the distinctive character of the religion of pre-Christian society. Blomkvist defines his own concept of 'ritualized tradition' as follows:

The concept of tradition has, during the last decades been a subject of a theoretical discussion mainly carried out by anthropologists and historians. Taking account of that discussion, I define ritualised tradition as activities generating norms, notions and ideas that get their legitimacy through the reference to an authoritative past. The term 'ritualised' implies that the activity is institutionalised and performed in such a way that it is perceived as a convention. The concept is suitable for a society (1) with a cult of the ancestors including belief in their ability to affect the lives of the living and (2) whose constitution is based on oral tradition. These two criteria can both be tied to activities relating to an authoritative past. An advantage of using ritualised tradition, to define a delimited social sphere, is that the concept, unlike religion, does not differentiate between the spheres of gods/goddesses, ancestors, law, politics and so on. Instead, the common denominator is the relation to the past. (Italics in original Blomkvist 2002, 196-7.)

There are several serious problems with Blomkvist's use of the concepts of 'ritualized tradition' and 'institutionalized religion'. One of these is his description of the religion of the pre-Christian period as characterized, more than other religions or at least more than the Christian religion of the Middle Ages, by its exclusive focus on tradition, custom and ritual activities. But traditions, customs and rituals form part of the religions of most societies, certainly including Medieval Christianity. Secondly, Blomkvist's construct of Medieval 'institutionalized religion' is questionable. It seems to be modelled on Protestantism, with its emphasis on personal, innate religiosity and the centrality of the belief system, whereas it is in fact well known that Medieval Catholicism emphasized religious practice (e.g. Pernler 1999, 82ff). I continue this discussion below.

Thirdly, Blomkvist's characterisation of the religious practices of the preChristian societies, based on the worship of ancestors and an 'authoritative

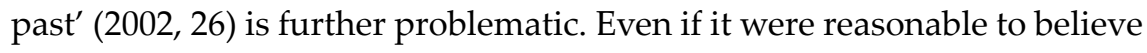
that the ancestors might have played a prominent role in the religious lives of pre-Christian peoples, there is hardly any evidence of an ancestor cult. The support for this idea offered by Blomkvist is based on a few ambiguous sources, which are susceptible to various interpretations. Further on, 
Blomkvist's notion of the ancestor worship seems to be modelled on the nineteenth-century theory of manism. This idea, presented by Spencer, places the ancestor cult as the primordial step in the evolution of religious forms. This armchair theory was seeking the answer to the origin of religion. Since it obviously lacks evidence in the empirical study of traditional religions, it has been abandoned in religio-historical studies.

One way to look closer at this interesting question might be to apply the method of ethnographic analogy, comparing Scandinavian pre-Christian religion to those of contemporary small-scale non-literate societies. Attention directed towards the ancestor spirits is a central trait in several non-literate religions (see Cox 2007, 53ff). However, many other traditional religions do not give the spirits of the dead a prominent role. At a general level, such a comparative approach may give us a better understanding of the various roles the ancestors might possibly have played in pre-Christian Scandinavia.

\section{Emic Conceptualizations}

Blomkvist's attempt to transform an emic concept, siðr, from the Saga literature into a category used at an etic level of analysis, in order to construct a new concept of the pre-Christian religious practices of the Scandinavian Iron Age, has several shortcomings. In the text discussed above and in a subsequent article coauthored with Olof Sundqvist (Blomkvist \& Sundqvist 2006), he claims, as already noted, that since the concept of religion is so permeated with conceptualizations taking Christianity as a model for religion, it distorts our understanding of the religion of pre-Christian times. Christianity is characterized by Blomkvist as an institutionalized and canonical religion, where the legitimization of power is based on the written word. He therefore argues that we need to find another term or category for pre-Christian societies. Blomkvist's understanding of religion, however, is entrenched in Protestantism, which is a biased preconception applicable neither to pre-Christian religion nor to Medieval Catholicism.

In connection with this discussion, Blomkvist further states: 'Another problem is the absence, in many societies, of indigenous concepts corresponding to "religion"' $(2002,196)$. My objection to Blomkvist's claim is that I do not think it a matter of importance whether or not small-scale and non-literate societies have concepts of their own referring to their religious conceptions and practices. That is to say, it is not relevant in deciding whether or not we can apply the category of religion in the study of these societies. 
An indigenous concept which can be translated into what is meant by our academic concept of religion is not something commonly occurring in such societies. They do not have such a concept because they have no need of one (Harvey 2000, 9). They are not interested in comparing their religious practices with those of other societies, which is a typical academic predicament of mostly western scholars. They simply refer to their religious practices as 'something we have always done' or 'the way of our ancestors', if they need to specify anything at all. This does not mean that they lack something that in an academic comparative aspect can be seen as expression of religion.

The practice among non-literate indigenous societies, in talking to an anthropologist, of referring to what we call religion simply with the expression 'because we always have done so', as Blomkvist himself formulates it $(2002,196)$, is one reason behind his suggestion that a new category for pre-Christian religion needs to emphasize the importance of religious practices. But does the need to focus on rituals justify a change of label for Pre-Christian Scandinavian religion? Merely to call it 'tradition' or 'custom' is too reminiscent of nineteenth-century evolutionary theories and their way of labelling pre-industrial religions as 'primitive'. 'Tradition' or 'custom' is essential to all religions.

Hence these arguments do not force us to abstain from using the concept of religion in speaking of the religious worlds of pre-Christian societies. In the same way that we speak for instance of prehistoric economies, kinship structures, social organization, cultural conceptions or ideologies, we can justify the use of the concept of religion. We do not need a whole range of indigenous concepts, replacing established categories, to analyse all these issues in different historical or cultural contexts. On the other hand, the study of indigenous concepts and conceptualizations, in their religious context, is naturally an important part of the process of understanding religious actions and conceptions.

Academic concepts are part of our scholarly enterprise and have evolved out of a European history of ideas. This does not mean that we cannot apply these concepts to the study of cultures and societies other than our own. Even though all concepts form part of a cultural discourse, I cannot agree that this means we are doomed to ethnocentrism when we apply for example the concept of religion. ${ }^{5}$

5 The problems of ethnocentrism and the situatedness of our academic concepts are a focal point in for instance Benson Saler's Conceptualizing Religion (1993, 227-64). Russell T. McCutcheon, in his Manufacturing Religion (1997, 131-2,148-52) and in a review (2000) also discusses this issue and reflects critically on the ideas put forward by Saler. Saler has subsequently commented on this in a written response (2000). 
The anthropologist Benson Saler has proposed that we make use of indigenous concepts from a given context 'as transcultural tools' in analyzing different religions (Saler 1993, 263). This method, he suggests, can help us transcend the biases inherent in our entrenched concepts $(1993,261)$.

Saler's recommendation, that we should try to find indigenous synonyms for the concept of religion, is in a way interesting, but only if these concepts are used to supplement our general analytical categories in their original historical contexts. The idea of finding an emic category, converting it into an etic one, and employing it as a useful analytical instrument in a different cultural context seems to me somewhat dubious. Indigenous concepts are important in the study of specific cultures, but in analyzing these cultures we need concepts that are applicable at a general level and categories that works in cross-cultural comparisons (cf. Bilde 1991, 11; McCutcheon 2000, 297).

We need generic concepts which are more or less generally applicable. Without the academic tool provided by analytical categories, the comparative study of religious behaviours becomes impossible (cf. McCutcheon 1997, 149; Paden 2000a). Only the comparative method can give us the perspective to understand both similarities and historical contingencies in different religious contexts. Saler $(1993,263)$ has declared his support for anthropology continuing to be a comparative discipline, although opposing views have been expressed by advocates of particularistic perspectives (e.g. Asad 1993). Nevertheless, Saler's proposal to turn indigenous concepts into academic categories is not convincing, nor am I persuaded of their usefulness in allowing us to transcend the cultural boundaries between 'us' and 'them' 'in the search for transcultural understandings' (Saler 1993, 9). Intended to help reduce possible western biases among scholars, it is nevertheless a problematic idea (McCutcheon 1997, 149f). The use of the problematic concepts of 'mana', 'taboo' and 'totemism' are old examples that in my view justify these objections. ${ }^{6}$

'Religion' is an ordinary term, used in everyday language in the western countries. This ordinary everyday usage of religion is situated in the histori-

6 In a written response $(2000,328)$ to reviews of his Conceptualizing Religion (1993), Saler pays attention to this remark, which was initially similarly made by Brian Morris $(1994,179)$. In his defense, Saler says that these concepts were poorly understood in their original settings, and that these kinds of biases are what he wants to get rid of. As a good example of his strategy, he proposes the concept of 'dharma'. Although Saler adds that the purpose of his strategy of making analytical categories out of emic terms is more of a stimulating experiment, I am not convinced that this method is an unproblematic remedy for ethnocentric biases. In any case, the inherent ambiguities in many emic categories make them no less complicated than 'religion' itself.'Dharma' is well-known for its definitional difficulties (Glucklich 2005). 
cal context of a modern liberal Protestantism; this is probably the reason why some scholars maintain that 'religion' is embedded in a biased western discourse. But the fact that religion is a western term, defined as an innate private religiosity, ought not to prevent us as scholars from using 'religion' as an academic concept with a different content. Religion can academically be applied as a transcultural analytical category that is not permeated by biases of everyday meaning. Nevertheless, the continuous revision of our terminology and the debating of our definitions in methodological studies is an important part of constructing useful categories and ridding them of ethnocentric biases.

We can understand Saler's proposal to apply indigenous concepts as a heuristic device to enrich our understanding of other cultures. Still, I think it can be a problematic strategy if the purpose is solely to get rid of scholarly ethnocentrism, since the concepts used by our informants always need to be interpreted and translated by the investigating scholar. Considering that scholarly conceptualizations are permeated by unconscious biases, these biases will be transferred to the emic terminology

Russell T. McCutcheon criticizes Saler's suggestion that the use of indigenous concepts as academic categories would reduce ethnocentric prejudices among scholars. As McCutcheon puts it, 'in his recommendations to employ indigenous terms on the path toward increased understanding [of religion], Saler's work may create more problems than it solves' (McCutcheon 1997, 132). Further on, McCutcheon stresses the problematic consequences that accompany the strategy of using emic concepts instead of academic categories, such as for example 'religion' and 'ritual', just because we may view them as entrenched in Eurocentric values:

The question to be pressed is whether such categories as 'religion', 'ritual', 'myth', 'institution', and the like, are themselves so entrenched in a particular worldview $[\ldots]$ as to make them inadmissible when used in cross-cultural, comparative research. If they are and if, [...] transnationalizing the field means ending our efforts to generate cross-culturally useful theoretical terminologies and comparative vocabularies in favour of using a multiplicity of local, indigenous, and emic terms [...] then the goal of developing widely applicable explanatory theories, rather than detailed scholarly description, is all but ruled out. (McCutcheon 1997, 149.)

Concerning the application of indigenous concepts to improve our understanding and interpretation of the different societies we study, Evans-Pritch- 
ard's eloquent comment on the one hand recognises its positive potential to highlight cultural contingencies, on the other warns us to keep this practice within modest limits:

One can, as has been done, use native words and then demonstrate their meaning by their use in different contexts and situations. But there is clearly a limit to this expedient. Reduced to an absurdity it would mean writing an account of people in their own vernacular. The alternatives are perilous. [...] One may, indeed, find some word or phrase in one's own language by which to translate a native concept. We may translate some word of theirs by 'god' or 'spirit' or 'soul' or 'ghost', but then we have to ask not only what the word we so translate means to the natives but also what the word by which it is translated means to the translator and his readers. We have to determine a double meaning; and at the best there can be no more than a partial overlap of meaning between the two words. (Evans-Pritchard 1965, 12-13.)

I do not oppose the use of emic concepts in general, for example in the ethnographies of different peoples. Quite the contrary: the use of emic concepts is necessary in studying cultural particulars in different societies, and the study of indigenous concepts is of great importance as a method of understanding emic conceptualizations.

The model proposed by Blomkvist is inspired by the suggestions presented by Saler. The way I see it, however, the method that Blomkvist urges us to apply is not merely a modification of Saler's proposition. According to Saler, 'anthropologists might borrow selectively from the categories of the peoples they study, and experiment with them for probing and describing the cultures of people who do not employ them' (Saler 2000, 327). The problems with Blomkvist's strategy are of another kind than merely the question of whether or not to apply emic concepts as heuristic devices. His model urges us to take an indigenous concept and convert it into an analytical concept to label the religious practices of the culture one is studying. In this case he wants us to use 'ritualized traditions', or the indigenous concept siðr, from which the former is derived, and to apply this instead of the generic category 'religion'. He thereby applies a subordinate category to replace the superordinate concept 'religion'. This is most troublesome because Blomkvist's category of 'ritualized tradition'/siðr does not include all the features that we as scholars define as religion. His category does not work at the same general level as religion. 
One further implication of Blomkvist's argument would seem to be that we, as scholars, would have to apply a different label to each individual religious tradition. This seems unreasonable; in fact, it would rule out the possibility of continuing the study of religion as a comparative transcultural discipline.

Thus the problem with the use of an emic concept, or a concept derived from an emic context, is its application as an etic category. In Blomkvist's case we may furthermore wonder how we can be sure that the original meaning of a concept is maintained once we have taken it out of its original context. Once it is lifted out of its original cultural discourse and converted into an analytical category, there is always the danger that we will impose different meanings and interpretations on this 'new' concept, since indigenous concepts when used by scholars are always part of a process of interpretation (cf. Jensen 2003, 109-11). Thus an important issue to consider is how these so-called 'new' concepts could be rid of biases and misconceptions.

\section{Traditions, Rituals and Religion as Practice}

In line with the aforementioned critics within the History of Religions and Social Anthropology, Blomkvist comments on the biased character of the academic use of the concept of religion. But he goes a step further when he suggests retaining the concept in connection with the Christianity of the Middle Ages, while using a different concept for the period preceding the introduction of Christianity in Scandinavia. This strategy is clearly problematic in many respects. While Blomkvist may have other intentions, one consequence of his reasoning is to make us wonder if he realises that in using these two different concepts - 'ritualized tradition' versus 'institutionalized religion' - he is referring to different categories. These two different terms obviously stand for what scholars commonly see as a single category, that of 'religion'.

The division between what Blomkvist calls the 'ritualized tradition' of the Scandinavian pre-Christian societies and the 'institutionalized religion' of the Middle Ages furthermore draws too sharp a boundary between the religions of small-scale, non-literate societies and those usually termed 'world religions'. While I agree with Blomkvist when he describes certain differences between the pre-literate, pre-Christian religion of Scandinavia and the subsequently introduced Christianity, I do not think these differences are sufficient to justify introducing two different concepts. The critique of Asad by Modée and McCutcheon, noted above, can also be applied to 
Blomkvist in this case. The different character of Scandinavian religion in the pre-Christian era and in the Middle Ages is an example of the diversity of the varied historical expressions of religion. At a certain level of generalization, we are studying the same kind of phenomena; I do not see why in these cases we cannot apply the category 'religion'.

In line with the ideas introduced by Blomkvist, some archaeologists are presenting similar questions regarding problems with the concept of religion. ${ }^{7}$ In these archaeological writings, however, these ideas are not analysed at any length; more often they have the character of brief second-hand statements. One of these scholars is the archaeologist Gunnar Nordanskog, who in his paper 'The "Völsung Legend" in Norwegian Stave Church Portals' (2003) presents views similar to those of Blomkvist:

The Christianising of Scandinavia is usually described in terms as 'shift of religions', but it should not be understood as a conversion in our modern sense between, say, Christendom and Islam. Whatever the Nordic pre-Christian faith was, it was not a formalised confessional religion with a corpus of holy texts. One might even ask whether the Scandinavian paganism should be viewed as a religion at all. (Nordanskog 2003, 397.)

In his thesis, Nordanskog (2006) develops these ideas even further. In his attempt to describe what he sees as the unique character of Scandinavian pre-Christian religion, his arguments are derived from Blomkvist. He then asserts that the religious discourse of the pre-Christian period cannot be characterized as a system of dogmas; rather, it should be described as a collection of traditions, of which ritual activities formed one part (Nordanskog 2006, 30). Similar arguments characterize the anthology Odin's Eye, published in connection with the exhibition by the same name; both the exhibition and the anthology evolved out of the interdisciplinary research project 'Roads to Midgard' (see below). In one of the contributions, the archaeologist Anders Andrén writes:

7 While I was completing this article, the edited volume Järnålderns rituella platser ['Ritual places of the Iron Age'] was published. In her contribution to this volume, the Danish archaeologist Charlotte Fabech presents a modification of the model of Blomkvist. In her discussion of the changes in ritual practices that took place in the middle of the first millennium in Scandinavia, Fabech describes this process as proceeding from 'ritualized traditions' of the early Iron Age to the 'institutionalized rituals' that evolved in the late Iron Age period $(2009,338)$. The term 'institutionalized religion', in her model, is used to label the religion of the Roman Empire of that time $(2009,336)$. The impact of Blomkvist's model on certain current archaeological studies is obvious. 
Scandinavian religion was not a confessional religion with holy scriptures and a professional priesthood. In its own days it was described as forn sidr, that is 'ancient customs' or the old way of life. There is thus a great deal to suggest that the religion should be regarded in the latter way, as diffuse and mutable. This means that we must try to understand the religious tradition and its history in other ways. (Andrén 2006a, 262.)

These suggestions echo Blomkvist's ideas. All these authors give us a debatable description of the differences between the religion of the pre-Christian societies and the subsequent Christian religion of medieval period in Scandinavia in particular, and between so-called world religions and the religions of small-scale non-literate societies in general. In their descriptions of the differences in these religious expressions, they certainly imply a demarcation that is not in line with contemporary research in History of Religions and Social Anthropology (see Cox 2007).

This dichotomization is problematic: it implies that the Scandinavian pre-Christian religion is characterized by ritual activities and customs, as opposed to the period of Christianity in this area, which these authors describe as a religion composed largely of beliefs authorized by holy scriptures and priests. This essentialising view of Christianity conceals the fact already pointed out, that the Medieval Catholicism is definitely a religion which can be described as action-oriented. Another serious implication of such reasoning is that Christianity is defined as a norm for religion, while pre-Christian religious expressions are categorized as a deviation from the norm, as 'non-religion'.

In addition, this model is questionable in two further ways. The first troublesome issue is that the so-called world religions, such as Christianity or Islam, are contrasted with so-called 'ritualized traditions'. This implicitly means that the things that these authors call 'traditions', 'customs' or other ritualized activities are seen as unimportant in such religions, which is simply not true. The religious worlds of Islamic or Christian societies are as much religions of practice and traditions, formed out of routines and rituals, as any other religious tradition (cf. Bilde 1991,16). Secondly, to describe the indigenous religion of the pre-Christian time in Scandinavia, and implicitly all other small-scale and non-literate religions, with a focus on rituals and other religious activities improperly implies that they lack beliefs and symbolic conceptions, or that these are less important. This is perhaps not what the authors of these ideas had in mind in defining the religion of the pre-Christian time, but it is a consequence of their argumentation. 
The editors of the conference volume Old Norse Religion (Andrén \& Jennbert \& Raudvere 2006), in defining Scandinavian pre-Christian religion in their introduction to the volume, echo the above-mentioned theories:

The Norse sources [...] use expressions like forn siðr 'old customs' or heiðnn sidr 'heathen custom' [...] The old days were thus denoted not only by their beliefs but just as much by the actions and behaviours that people had performed: religious acts, judicial acts, behaviour to mark ownership and belonging. An expression like 'the old custom' has far-reaching connotations: the traditional, regular practice, but also with a knowledge of the past. [...] The conventional scholarly use of the term religion is therefore not really applicable. (Andrén \& Jennbert \& Raudvere 2006, 12.)

This quotation sums up the definition of pre-Christian religion presented in the large interdisciplinary project Roads to Midgard - Norse Paganism in Long-term Perspectives, of which this conference volume is one part. The authors' narrow definition of 'religion', however, is not convincing. Why is the concept of religion not applicable in this case? Their arguments are unsatisfying, since 'religion' definitely does include contexts of 'everyday, ritual, and habitual behaviours' (ibid). The way these authors picture the so-called conventional scholarly use of the concept of religion is not in line with contemporary studies in the History of Religions.

Further on in the introductory texts to Old Norse Religion, the three editors continue to present their new approach as a change of perspective, '[b]y switching the focus from myth to rite' $(2006,13)$. The emphasis on ritual as a particular focus in the study of prehistoric religions is stressed by other archaeologists as well. This focus is reasonable, in that archaeological remains are traces of past practices. However, the way some archaeologists define religion and ritual implies a problematic understanding of the nature of ritual practices and their embeddedness in symbolic meanings and beliefs.

In the introductory text to the anthology Dealing with the Dead (2005), the archaeologists Tore Artelius and Fredrik Svanberg inform us of their definition of ritual and religion:

In order to highlight religious ideas, a theory of the significance of collective religious rituals is used which works from the premise that religion is ritual and ritual is religion, an idea found in the theorising of scholars such as Claude Lévi-Strauss and Roy Rappaport (Artelius \& Svanberg 2005, 12). 
This quotation is full of contradictions. If one is interested in religious conceptions, why would one prefer to emphasize the importance of rituals in religions? Later, we are told that ritual is a concept that can be used synonymously with religion, which is an inadequate approach to the analysis of religion. Ritual is clearly a subcategory and forms an important part of what we mean by the academic category of religion. The references to Lévi-Strauss and Rappaport in support of such claims are even more puzzling, since neither of them would posit any such thing. Especially the reference to Lévi-Strauss is difficult to understand. If one is emphasizing the importance of religion as action-oriented, why use him as a reference? He is well-known for his position that anthropology is the study of 'thought' (Morris 1987, 267).

In the field of History of Religions, scholars inspired by practice theories stress religious actions in reaction against the biased emphasis on beliefs in previous studies of religion (e.g. Bell 1992). Inspired by these theories, archaeologists assert the need for action-oriented perspectives. However, the claim that the focus on ritual studies in pre-Christian times is a new and a more accurate perspective on Scandinavian pre-Christian religion is problematic in several respects.

In older philological studies on Scandinavian pre-Christian religion, the main focus has often been on belief systems and mythology. The reason behind this dominance of perspective is due to the focus in these studies on written sources. While the written sources on religion primarily describe mythological conceptions, this does not necessarily mean that the authors of these older studies were unaware of the importance of ritual in religion.

In a way, this archaeological demand for an emphasis on ritual is understandable. The arguments and the alleged new perspective, however, are not convincing. I cannot see the advantage of focusing on religious practices at the cost of minimizing the importance of belief systems or symbolic conceptions. What is astonishing is that some archaeological authors view archaeological findings as a more or less uncomplicated source of information on Scandinavian pre-Christian religion, while they critically stress the problematic nature of the Old Norse literature (e.g. Blomkvist: 2002, 43f; Andrén 2006b, 62f; Nilsson Stutz 2006, 95; cf. Nordanskog 2003, 5 and Andrén 2006a, 262f).

One cannot really describe a religion without taking into account both rituals and mythological and symbolic conceptions; they are interactive parts of a whole (cf. Godlove 2002; cf. Jensen 2003, 40-2). Why, then, do we need 
to overemphasize the importance of ritual activities in pre-Christian studies? Perhaps this is not the intention of such remarks; some archaeologists of religion, however, seem to be implying that the study of ritual is more important than the study of beliefs and symbolic conceptions, unwittingly offering this as a completely new perspective on the study of Scandinavian pre-Christian religion.

The rituals of pre-Christian people are less easy to understand in the context of the archaeological sources than some of these authors assume. The over-emphasis on ritual is problematic, since ritual practices are often permeated with symbolic conceptions. Without any knowledge of such cultural conceptions, it is impossible to understand ritual practices. Attempts by archaeologists to reconstruct religious activities from the fragmentary material remains at a prehistoric site are an even more complex undertaking. While this is of course a fascinating task and an exciting challenge, one cannot stress enough the complexities involved in the project of reconstructing past religions.

\section{Heterogeneity and Hyper-Particularism}

Various archaeologists have criticized prior perspectives which presented pre-Christian religion as a homogenous and static tradition, claiming that religious expression during the time up to the Medieval period was characterized by heterogeneous activities that changed over time and that varied between the different regions of the European North (cf. the discussion of Blomkvist above). The archaeologist Fredrik Svanberg describes his perspective as follows:

Many scholars believe, for example, that death rituals are a direct reflection of religious ideas, and it is then obvious that pre-Christian religion differed considerably in both ideas and practice from one area to another. Differences in ritual traditions show that there was no uniform religion during the Late Iron Age. The pre-Christian religion consisted of a diversity of changing traditions and variations, and therefore contrasted sharply with the relatively uniform Christianity. (Svanberg 2006, 301.)

This statement is problematic in several respects. When Svanberg refers to differences in the ritual traditions of the Iron Age and how these reflect religious ideas, he is probably speaking of differences in the archaeological remains, not in rituals. The archaeological material may very well reflect 
some part of the rituals, especially in the case of burial remains such as those Svanberg is referring to, but we can never be certain of the symbolic activities behind these remains. ${ }^{8}$ The claim that rituals are a direct reflection of religious conceptions is problematic, and cannot be supported by studies in the History of Religions (see Bell 1997).

Svanberg further implies that the variation in the material remains of burials is a direct reflection of religious ideas, thereby arriving at the conclusion that the religion of this period was not a uniform tradition. However, he suggests that the cultural material is a direct reflection of religious conceptions, and this is far too simplistic. In his attempt to interpret religious variation, Svanberg seems to be exaggerating the differences in archaeological remains; an overall perspective on the pre-Christian and Late Iron Age Scandinavian area reveals many similarities in material expressions. Furthermore, there are many possible interpretations of variation in the archaeological remains (cf. Kaliff 2007, 64).

In the above quotation, Svanberg further says that rituals and conceptions changed over time and between locations. This is not controversial. Rituals, religions, cultural conceptions and societies are not static; since these religions lack a central authority that coordinates practices, they are bound to show regional variation.

Blomkvist, Andrén and others have been expressing similar ideas about variation and change, as proposed by Svanberg (e.g. Andrén \& Jennbert \& Raudvere 2006, Andrén 2006b, 62; Blomkvist \& Sundqvist 2006, 35-6). In their Introduction to Old Norse Religion, the editors suggest that pre-Christian religion of the late Iron Age has been shown not to be 'a uniform or a stable category' (Andrén \& Jennbert \& Raudvere 2006, 13). Further on they allege the presence of 'profound chronological, regional, and social differences in pre-Christian religious practice in Scandinavia [...] [t] he archaeological traces of rites are in fact so different in time and place that one can seriously question the term “Norse paganism"' (Andrén \& Jennbert \& Raudvere 2006, 13-14).

This depiction of the religion of the late Iron Age as completely different in each individual region is not plausible. It is based on unproblematized ideas of historical particularism and an inadequate understanding of the nature of religion in simple societies. The suggestion concerning the Scandinavian societies as totally influenced by the religions of neighbouring

8 For the complexities involved in reconstructing prehistoric rituals and the symbolic conceptions that permeate these practices, see the interesting comments by the archaeologist Timothy Insoll $(2004, x i i i-x v, 19)$ and the anthropologist Edmund Leach $(1977,166)$. 
societies is likewise unconvincing, since it lacks informed discussion on processes of acculturation and diffusion. These suggestions (e.g. Blomkvist 2002; Andrén 2006b, 69ff; Andrén \& Jennbert \& Raudvere 2006, 14; Svanberg 2006) are not in line with contemporary studies of the History of Religions (cf. Drobin 2007). It is most plausible that many shared religious ideas and practices were present in this area, and that the many similarities in the material culture of the late Iron Age in Scandinavia can sustain such a picture. Religious variations and historical changes naturally did occur; but I think a better approach to understanding these differences in practices and beliefs would be to see them as variations on a theme.

Some interesting parallels can be drawn in analogy to anthropological studies of religion in Africa. In his study of the traditional religion of the people of Malawi, Brian Morris (2000) has shown that even though this country is composed of several ethnic groups, the many religious conceptions and rituals, while slightly varying, are shared throughout the whole country. The presence of shared social institutions and cultural representations, according to Morris, is due to the common origins and historical traditions of these groups, and to their long-standing cultural, economic and linguistic interrelationships. This comparison offers an interesting understanding of how religious ideas and practices, even if they differ in some aspects, can be traced back to a shared common substratum.

Thus it is the trend in post-modern theories in Social Anthropology and History of Religions of emphasizing the importance of a particularistic perspective that has inspired these archaeologists and religio-historical scholars of Scandinavian pre-Christian religion. These perspectives foreground the uniqueness of different cultural expressions. According to the authors discussed here, previous scholars have missed the importance of religious variations and the fact that religions change over time and place; these assertions, however, are not often supported by any reference to theoretical studies of cultural or religious change in for example current anthropological and religio-historical scholarship.

I do not in general disagree with claims that foreground the importance of the cultural uniqueness of each individual society and form of religious expression, although I also recognize the importance of studies of general patterns in a larger perspective. The study of cultural differences is as important as acknowledging similarities in a cross-cultural perspective (Paden 2000b; Jensen 2003). That religions are far from static is obvious. The form in which these archaeologists present their models of religious change and variation, however, is problematic in several respects. 


\section{Conclusion}

The debate on the concept of religion in the History of Religions and in anthropological studies has in many ways enriched our understanding of religious expressions. However, I do not think that the concept of religion as an academic category is necessarily entrenched in a folk definition of western culture, in which religion is defined in a Christian Protestant manner as private innate belief and as internal religious feelings experienced by the individual. I therefore do not agree with those scholars who argue that it is inappropriate to apply the academic concept of religion to the study of other cultures than our own. While the definition of religion has a history of contentious debate, I do consider that a study of religion that is not embedded in Christianized and essentialist assumptions is possible.

Thus, when various Swedish scholars of Scandinavian pre-Christian societies put forward a critique of the concept of religion, claiming that this concept is based on Christianity as a model for religion, thus making us misconceive the religion of pre-Christian times, I have to disagree. The approaches of the authors who proclaim such ideas have several shortcomings, quite apart from the fact that the concern over misconceptions and ethnocentrism embedded in the concept of religion is clearly exaggerated.

The shortcomings of the ideas and perspectives proposed by these scholars with regard to the definition of pre-Christian religion can be criticized from three different points of view. First of all, the demand to discard the concept of religion in pre-Christian studies, replacing it with an emic category at an etic level, has several problematic consequences. This argument implies that we should develop different labels for every single religion: a most troublesome strategy, since it would prevent us from making cross-cultural comparisons and maintaining the study of religion as a transcultural field. But if this is not possible, how can we develop widely applicable explanatory theories and analytical categories? The second problem with this approach is the inappropriate dualistic opposition between Scandinavian pre-Christian religion and Christianity. Following this model of opposition, the pre-Christian period is described simplistically as having a religion consisting of practices. The third and final point is the way these authors improperly describe the religion of the pre-Christian period as so different in every region of Scandinavia that we cannot speak of shared religious ideas or practices in the late Iron Age. While of course all societies and religious traditions naturally change over time and vary from place to place, the model of change and diversity presented by these writers is overly simplistic and one-sided. 
The demand to abandon the concept of religion in pre-Christian studies has many consequences, one of which is even more severely ethnocentric than the biases from which these authors are trying to escape. Thus, when Blomkvist, Nordanskog, Andrén, Svanberg and others suggest that the religion of this period consisted simply of ritual traditions, as opposed to the confessional and systematized religion of Christianity, they are unwittingly following in the footsteps of the theories of the differences between religion and magic postulated by the evolutionists of the nineteenth and early twentieth century (cf. Evans-Pitchard 1965, 3; Cox 2007, 2). The idea of applying the concept of religion exclusively to what evolutionist scholars felt was the 'civilized' and 'authentic' Christian religion of western nations, and using the pejorative labels 'magic' and 'superstition' for the religious worlds of what were depicted as pagan and primitive societies, has long since been abandoned in the History of Religions.

One important consideration in the study of small-scale non-literate religions is stressed in the introduction to the volume Indigenous Religions, edited by Graham Harvey. For some of us this is perhaps a patently obvious claim, but I would like to stress it once again:

What makes indigenous religions important $[\ldots]$ is not that they are necessarily different from - and especially not more 'simple', 'primitive' or less complex than - other ways of being human (Harvey 2000, 3).

In dealing with the question of what counts as religion and who has the power to decide this, it is important to recognize that decisions made by scholars can have political consequences as well. If for example it were suggested that the Saami people, or any other indigenous society, did not have a 'proper' religion in pre-Christian times, but only some form of tradition - as has in fact been claimed by many evolutionist scholars - this would certainly give rise to loud protests (cf. Drobin \& Keinänen 2001, 161-2).

In the process of criticizing the weaknesses of past methods and in searching for better ones, it is important to remember that a new perspective is not necessarily better or less problematic simply because it is new. There is always the risk that a so-called 'new' approach is just another way of misconceiving the object of study. In the effort to reduce bias in our academic enterprise, the importance of self-reflection can never be overstated.

In describing the religion of pre-Christian Scandinavian societies with the category 'ritualized tradition' or any other such concept, I believe that we are imposing ideas of primitivism on these societies. This religion was 
certainly not merely an uncomplicated conglomeration of customs and practices. Replacing the concept of religion with that of ritualized tradition/forn siðr/custom/ritual activities may thus create far more problems than it solves.

Last but not least, I wish to emphasize that both the field of Scandinavian pre-Christian religion in particular and the archaeology of religion in general may gain new insights from the theories and methods evolved in the contemporary phenomenology of religion. The strategies outlined for instance by William Paden and Jeppe Sinding Jensen, in what they have called 'a new comparativism' or 'a post-phenomenology of religion', have led to solutions to many of the problems in old paradigms, and have given rise to new approaches to comparative studies, in line with more up-to-date methodological and theoretical approaches (Paden 2000b; Jensen 2003). The comparative method and various analogies might provide us with relevant questions to direct to the archaeological material. This method of analogies can guide us towards an increased understanding of the religious worlds of the pre-Christian period. The study of the religion of the Scandinavian late Iron Age, and earlier periods, can benefit if it evolves analogously to studies of the religions of small-scale non-literate societies. Along with archaeological and written sources, the common elements or characteristics shared with traditional and non-literate religions in the world today can enhance our ability to create well-founded reconstructions of the religions of the Scandinavian pre-Christian period.

\section{Bibliography}

Ahn, Gregor

1997 Religion. - Gerhard Müller (ed.), Theologische Realenzyklopädie 28, 513-22. Berlin: Walter de Gruyter.

\section{Andrén, Anders}

2006a Scandinavian Religion in Time and Place. - Anders Andrén \& Peter Carelli (eds), Odin's Eye - Between People and Powers in the Pre-Christian North, 262-7. Lund: Dunkers Kulturhus.

2006b Ett omöjligt uppdrag? Att studera nordisk förkristen religion. - Kungl. Vitterhets historie och antikvitetsakademins årsbok 2006, 61-77.

Andrén, Anders \& Kristina Jennbert \& Catharina Raudvere

2006 Old Norse religion. Some Problems and Prospects. - Anders Andrén \& Kristina Jennbert \& Catharina Raudvere (eds), Old Norse Religion 
in Long-Term Perspective: Origins, Changes, and Interactions, an International Conference in Lund, Sweden, June 3-7 2004, 11-14. Lund: Nordic Academic Press.

\section{Artelius, Tore \& Fredrik Svanberg}

2005 Dealing with Scandinavian Burial Ritual - An Introduction. - Tore Artelius \& Fredrik Svanberg (eds), Dealing with the Dead. Archaeological Perspectives on Prehistoric Scandinavian Burial Ritual, 5-17. Stockholm: The Swedish National Heritage Board: The Museum of National Antiquities in Sweden. (Riksantikvarieämbetet, Arkeologiska undersökningar skrifter, 65.)

\section{Asad, Talal}

1983 Anthropological Conceptions of Religion: Reflections on Geertz. - Man 18, 237-59.

1993 Genealogies of Religion: Discipline and Reasons of Power in Christianity and Islam. Baltimore: Johns Hopkins University Press.

\section{Bell, Catherine}

1992 Ritual Theory, Ritual Practice. New York: Oxford University Press.

1997 Ritual. Perspectives and Dimensions. New York: Oxford University Press.

\section{Beyer, Peter}

1998 The Religious systems of Global Society: A Sociological Look at Contemporary Religion and Religions. - Numen 45, 1-29.

2003 Conceptions of Religion: On Distinguishing Scientific, Theological, and 'Official' Meanings. - Social Compass 50, 141-60.

Bilde, Per

1991 Begrebet religion. Et indlæg i debatten om religionsvidenskabens objekt drøftet i lyset af beslægtede begreper. - Chaos 15, 3-24.

\section{Blomkvist, Torsten}

2002 Från ritualiserad tradition till institutionaliserad religion: strategier för maktlegitimering på Gotland under järnålder och medeltid. Uppsala: Teologiska institutionen, University of Uppsala.

\section{Blomkvist, Torsten \& Olof Sundqvist}

2006 Religionsbegreppets tillämpning i handböcker om fornskandinavisk och germansk religion. - Birgit Lindgren Ödén \& Peder Thalén (eds), Nya Mål? Religionsdidaktik i en tid av förändring, 20-37. Uppsala: Swedish science Press. (Religionsvetenskapliga studier från Gävle 2.)

\section{Cox, James L.}

2007 From Primitive to Indigenous. The Academic Study of Indigenous Religion. Aldershot: Ashgate. 


\section{Drobin, Ulf}

2007 Det fanns en välutvecklad religion i det forna Norden. - Henrik Persson \& Ola Persson (eds), Mångkultur, minoritet och tro, 44-9. Stockholm: Föreningen Fjärde världen. (Kulturdebatt II.)

\section{Drobin, Ulf \& Marja-Liisa Keinänen}

2001 Frey, Veralden Olmai och Sampo. - Michel Stausberg (ed.), Kontinuitäten und Brüche in der Religionsgeschichte. Festschrift für Anders Hultgårdh zu seinem 65. Geburtstag am 23.11.2001, 136-68. Berlin/New York: Walter de Gruyter. (Ergängzungsbände zum Reallexikon der Germanischen Alterumskunde 31.)

Evans-Pritchard, E. E.

1965 Theories of Primitive Religion. Oxford: Oxford University Press.

\section{Fabech, Charlotte}

2009 Fra ritualiseret tradition til institutionaliserede. - Anne Carlie (ed.) Järnålderns rituella platser, 317-42. Lund; Grahns tryckeri (Stiftelsen Hallands Länsmuseer: Kulturmiljö Halland, 9.)

\section{Fitzgerald, Timothy}

1997 A Critique of 'Religion' as a Cross-Cultural Category. - Method and Theory in the Study of Religion 9, 91-110.

\section{Geertz, Armin W.}

1996 Begrebet religion endnu engang. Et deduktivt forsøk. - Chaos 26, 109-28.

\section{Geertz, Clifford}

1973 The Interpretation of Cultures: Selected Essays. New York: Basic Books.

\section{Glucklich, Ariel}

2005 Dharma: Hindu Dharma. - L. Jones (ed.), Encyclopedia of Religion 4, 2nd ed., 2327-31. Detroit: Macmillian Reference USA.

\section{Godlove, Terry F. Jr}

2002 Saving belief. On the New Materialism in Religious Studies. - Nancy K. Frankenberry (ed.), Radical Interpretations in Religion, 10-24. Cambridge: Cambridge University Press.

\section{Harvey, Graham}

2000 Introduction. - Graham Harvey (ed.) Indigenous Religions. A Companion, 1-19. London: Cassell.

Insoll, Timothy

2004 Archaeology, Ritual, Religion. London: Routledge. 


\section{Jennbert, Kristina}

2000 Archaeology and Pre-Christian Religion in Scandinavia. - Current Swedish Archaeology 8, 127-41.

\section{Jensen, Jeppe Sinding}

2003 The Study of Religion in a New Key. Theoretical and Philosophical Soundings in the Comparative and General Study of Religion. Aarhus: Aarhus University Press.

Joy, Morny

2008 Method and Theory in Religious Studies: Retrospect and Prognostication. - Temenos 43 (2), 199-222.

\section{Kaliff, Anders}

2007 Fire, Water, Heaven and Earth. Ritual Practice and Cosmology in Ancient Scandinavia: An Indo-European Perspective, Stockholm: Riksantikvarieämbetet.

\section{Kværne, Per}

1973 'Comparative Religion: Whiter - and Why?' A Reply to Wilfred Cantwell Smith. - Temenos 9, 161-72.

\section{Leach, Edmund}

1977 A View from the Bridge. - Matthew Spriggs (ed.), Archaeology and Anthropology: Areas of Mutual Interest, 161-76. Oxford: British Archaeological Reports. (Supplementary Series, 19.)

\section{McCutcheon, Russell T.}

1997 Manufacturing Religion. The Discourse on Sui Generis and the Politics of Nostalgia. New York: Oxford University Press.

2000 Taming Ethnocentrism and Trans-Cultural Understandings. - Method and Theory in the Study of Religion 12, 294-305.

\section{Modée, Johan}

2005 Artifacts and Supraphysical Worlds. A Conceptual Analysis of Religion. Lund: Centre for Theology and Religious Studies, Lund University.

\section{Morris Brian}

1987 Anthropological Studies of Religion. An Introductory text. Cambridge: Cambridge University Press.

1994 Review of Benson Saler, Conceptualizing Religion. - Method and Theory in the Study of Religion 6, 177-9.

2000 Animals and Ancestor. An Ethnography. Oxford/New York: Berg.

\section{Nilsson Stutz, Liv}

2006 Escaping the Allure of Meaning. Toward new paradigms in the study of ritual in Prehistory. - Anders Andrén \& Kristina Jennbert \& Catharina Raudvere (eds), Old Norse Religion in Long-Term Perspective: 
Origins, Changes, and Interactions, an International Conference in Lund, Sweden, June 3-7 2004, 95-8. Lund: Nordic Academic Press.

\section{Nordanskog, Gunnar}

2003 The 'Volsung Legend' in Norwegian Stave Church Portals - Meaningless Decoration or Conscious Use? - R. Simek \& J. Meuer (eds), Scandinavia and Christian Europe in the Middle Ages. Papers of the 12th International Saga Conference Bonn/Germany, 28th July-2nd August 2003, 293-402. Bonn: Hausdruckeri der Universitet Bonn.

2006 Föreställd hedendom. Tidigmedeltida skandinaviska kyrkportar i forskning och historia. Lund: Nordic Academic Press. (Vägar till Midgård, 9.)

Paden, William E.

2000a Prototypes: Western or Cross-cultural? - Method and Theory in the Study of Religion 12, 307-13.

$2000 \mathrm{~b}$ Elements of a New Comparativism. - Kimberly C. Pattorn \& Benjamin C. Ray (eds), A Magic Still Dwells. A Magic Still Dwells: Comparative Religion in the Post-Modern Age, 182-92. Berkeley: University of California Press.

\section{Pernler, Sven-Erik}

1999 Sveriges kyrkohistoria. Hög- och senmedeltid. Stockholm: Verbum.

\section{Saler, Benson}

1993 Conzeptualizing Religion. Immanent Anthropologist, Transcendent Natives, and Unbounded Categories. New York: Berghahn.

2000 Conceptualizing Religion: Responses. - Method and Theory in the Study of Religion 12, 323-38.

\section{Smith, Jonathan Z.}

1982 Imagining Religion. From Babylon to Jonestown. Chicago: University of Chicago Press.

1998 Religion, Religions, Religious. - Mark C. Taylor (ed.), Critical Terms of Religious Studies, 269-84. Chicago: University of Chicago Press.

\section{Smith, Wilfred Cantwell}

1978 (1962) The Meaning and End of Religion. San Francisco: Harper \& Row.

\section{Sundqvist, Olof}

2005 Siðr. - H. Beck et al. (eds) Reallexikon der Germanischen Alterumskunde 28, 273-6. Berlin, New York: de Gruyter.

\section{Svanberg, Fredrik}

2006 Death Rituals, Identity and Religion. - Anders Andrén \& Peter Carelli (eds), Odin's Eye-Between People and Powers in The Pre-Christian North, 299-301. Lund: Dunkers Kulturhus. 


\section{Tylor, Edward Burnett}

1970 [Primitive Culture, 2.] Religion in Primitive Culture. Gloucester, Mass.: Harper \& Row. (Orig. publ. as chapter XI-XIX of Primitive Culture, 1871.) 
